\title{
The Transcivilizational Perspective: A Legitimate and Feasible Approach to International Law
}

LI Ming*

Peking University, People's Republic of China

lmI957@pku.edu.cn

Professor Onuma is the first international lawyer in the world to advocate a transcivilizational perspective to the study of international law. In his recently published treatise International Law in a Transcivilizational World, ${ }^{\mathrm{T}}$ he re-emphasized the significance of this perspective in international legal study, ${ }^{2}$ and analyzed and evaluated specific issues of international law with it. The transcivilizational perspective (hereinafter referred to as "TCP") makes the book unique compared with general works of international law, and it is also what this author is most interested in. This author believes that TCP addresses questions not only about legitimacy but also about feasibility, and is thus a valuable innovation in the theory of international law. Furthermore, it provides a meaningful reference for the theoretical exploration of Chinese international lawyers.

I.

International law is the product of modern Western Christian civilization. It was spread throughout the world with the colonial expansion of the West starting from the sixteenth century. The Western powers opened the gate of ancient civilizations one after another by firm ships and advanced artillery, and brought Western culture to them, including international law.

However, in the process of Western colonial expansion, these ancient civilizations were excluded from the so-called civilized countries, and their people were even

\footnotetext{
* Professor of Law, Peking University

I. Yasuaki ONUMA, International Law in a Transcivilizational World (Cambridge: Cambridge University Press, 20I7).

2. Onuma has pursued what he considered a more legitimate, or what he called a "transcivilizational" perspective of international law in his research since the I980s; ibid., at 2.
} 
regarded as barbarians. What international law brought to them was mainly jus ad bellum, the annexation or cession by force, unequal treaties, consular jurisdiction, and leasehold land etc. International law became a tool for imperialism.

This situation had not begun to improve until the arrival of the United Nations era. Along with the process of decolonization, a large number of exploited and oppressed colonies became independent and legally equal sovereign states. They were adopted as UN members and participated positively in the process of international law to advocate and defend their own rights. International law, as the law among sovereign states, has gained a globally universal significance since then.

However, the effectiveness of international law cannot be separated from power. In this sense, the current international order is still dominated by the West. The international law of the twentieth century is Euro-/American-centric international law. ${ }^{3}$ The West has always been in command of the discourse of international law with their hard as well as soft power.

TCP is the outcome of Professor Onuma's reflection on Euro-/American-centric international law. In his view, this perspective is a crucial path to rectify Euro-/American-centric international law. The international law of the twenty-first century should be a transcivilizitional international law. ${ }^{4}$ The definition of the perspective by Professor Onuma is somewhat complicated in his book. ${ }^{5}$ According to my understanding (which may not be completely accurate), the perspective is a method of studying the process of international law based on various civilized and cultural factors. The process, according to this approach, should include, but is not limited to, the making, interpretation, application, and evaluation of international law; should fully reflect the histories and traditions of various civilizations; and should present the inclusiveness of them all.

TCP is legitimate. This legitimacy should come from the universality of international law. ${ }^{6}$ If international law is to be worthy of its name and intends to become a law universally respected and obeyed by states with different civilizations and cultures, it must listen to the voices of them all, and must be able to include different voices. This should be the proper meaning of globally universal international law, which is confirmed by the Statute of the International Court of Justice [ICJ]. It requires elected judges to represent the world's major legal systems. The globally universal significance of international law needs mutual inclusiveness among civilizations, and this is where the legitimacy of TCP lies.

3. Onuma says that he has certainly been critical of the prevalence of Euro-centric or West-centric ways of thinking in international law for years; ibid., at 2.

4. Onuma believes that the study of international law in the twenty-first century must overcome the narrowness of the West-centric and positivistic study of international law and better use a transcivilizational perspective; ibid., at 15 .

5. Ibid., at I9.

6. But according to Onuma, the rapid growth of the economic power of some countries with ancient civilizations will strengthen their discourse in international law in the twenty-first century. This seems to explain only the effectiveness of future international law, not the legitimacy or authority of it; ibid., at I-6. 


\section{II.}

TCP is also the result of Professor Onuma's reflection on state-centrism in international law. Since the end of the nineteenth century, positive international law has triumphed over natural law, and it has always been the mainstream of international law. Positivism advocates state-centrism. States are both the producers and consumers of the law. The law comes from the consent of the states, and the states' consent is presented as treaty and custom. Thus, international law is mainly the law among states. It is an acceptable assumption that states and their relationships are the basis of international law. And it accords with the facts. This is why any reflections or criticisms on positive international law cannot depart from it completely.

Professor Onuma acknowledges the rationality of the state-centrism of international law. His transcivilizational perspective intends to rectify and supplement positive international law to overcome its narrowness. ${ }^{7}$ In his view, the study of international law cannot be confined either to the principles and rules of international law themselves, or to the technical interpretations of them. Instead, it should take the history, traditions, and culture of each state fully into consideration, so as to better understand and interpret the process of international law from a broader view. ${ }^{8}$

Although TCP is only a complementary approach, as Professor Onuma suggests, it still has theoretical innovative significance in international law. Since it provides an unprecedented perspective for observing, understanding, and interpreting international law, it creates a new possibility for reshaping international law under new historical conditions. Although Samuel P. Huntington has incisively discussed the roots of international conflicts from the perspective of civilization in his book The Clash of Civilizations and the Remaking of World Order, the book is not one of international law in a strict sense. It is Professor Onuma who is the first scholar to study international law from the perspective of world civilizations. Perhaps more importantly, the two hold different philosophies. Huntington inherited Hobbes' assumption that evil is human nature, talking about the conflict between civilizations. In contrast, Onuma, with the inheritance of the Confucian goodness of human nature, emphasizes the inclusiveness of civilizations. The two are completely different in their mapping of the future.

\section{III.}

TCP is not only legitimate, but also feasible. It can be a useful tool for international legal study. Professor Onuma has always used it to analyze international legal phenomena and has gained important academic achievements. ${ }^{9}$ In this book, we can also see the value of its application. Now, this author would like to elaborate on the

7. Ibid., at 19 .

8. Ibid., at 9, $2 \mathrm{I}-2$.

9. One of his books was translated into Chinese and introduced to Chinese readers in I997: Yasuaki ONUMA, Human Rights, States and Civilizations (Beijing: SDX Joint Publishing Company, I997). 
feasibility of this perspective as a research tool, taking China's view of sovereignty as an example.

In 1949, the government of the People's Republic of China was established. At that moment, Chairman Mao Zedong announced to the world: "The Chinese people have stood up." This sentence is full of the historical memory of the Chinese, and can be used to reasonably explain the new government's understanding of sovereignty in international law.

The modern history of China is a history of the humiliation of the Chinese people. In I 842, Britain opened the gate of China by force. Western and Eastern powers have since flooded into China. They forced the Qing government to sign a series of unequal treaties. These treaties not only caused the Qing government to cede territory and pay indemnities, but also enabled the powers to take a large number of privileges in China, such as consular jurisdiction, the sphere of influence, garrisoning on leasehold land, the embassy district, and the railways. As a country with a long history and ancient civilization, China had since fallen into a semi-colony of powers.

This history has left a lasting memory for the Chinese people. It was this historical memory that made the new Chinese government develop its own understanding of the concept of sovereignty. "The Chinese people have stood up" signifies that China has been freed from the history of semi-colonial exploitation and oppression; signifies that China will stand rock-firm in the family of nations; and signifies that China will autonomously determine its future destiny. Sovereignty is by no means an abstract word. It is a reflection of history. It represents independence, dignity, equality, and selfdetermination for the new government.

It is the same historical memory that prompted China, India, and Myanmar to jointly advocate the Five Principles of Peaceful Coexistence in I954, and that promoted the convening of the 1955 Bandung Conference and the promulgation of the ten principles by Asian and African countries at the conference. A paragraph from the address of the Indonesian President at the Opening Ceremony of the Bandung Conference expressed the resonance of all the participants with their common historical memory:

For many generations our peoples have been the voiceless ones in the world. We have been the un-regarded, the peoples for whom decisions were made by others whose interests were paramount, the peoples who lived in poverty and humiliation. Then our nations demanded, nay fought for independence, and achieved independence ... ${ }^{\text {IO }}$

The historical memory is the vocabulary used by this author. Actually, it is equal to the words "mindset of victims" ${ }^{\text {II }}$ or "a sense of humiliation" ${ }^{\mathrm{2} 2}$ that Professor Onuma uses. The historical memory or the mindset of victims should be of great help in

Io. See opening address given by Sukarno at the Bandung Conference (I 8 April I95 5 ), Bureau of Archives of the Ministry of Foreign Affairs of the People's Republic of China (ed.), Selective Collections of Diplomatic Archives of the People's Republic of China, Volume II: Participation of the Chinese Delegation in the I955 AsiaAfrican Conference (Beijing: World Affairs Press, 2007) at I 30.

II. Onuma, supra note 9 at $8, \mathrm{I} 7$.

I2. Onuma, supra note I at $6, \mathrm{n}$ I. 
explaining the position of the international law of states with ancient civilizations, including China. It can also explain the necessity for civilization inclusiveness, especially at present when new international conflicts break constantly. TCP is not only a theoretical innovation in international law, but also a valuable one.

IV.

Finally, I would like to talk briefly about the possible role of TCP in Chinese scholars' theoretical innovation in international law. Theoretical innovation is what many Chinese scholars are dedicated to. The idea of "building a community of shared future for mankind" proposed by the Chinese government has become a hot topic of this innovation. This idea consists of five value goals: lasting peace, common security for all, common prosperity, openness and inclusiveness, and cleanness and beauty. The final goal is human happiness. Some scholars try to construct their theories or theoretical innovations from this idea and take its value goals as orientation. This work is of great significance; nevertheless it is also very cumbersome and complicated, because the idea and its value goals are highly abstract and require abundant interpretations and justifications.

In my view, this idea combined with its value goals and TCP share two similarities or commonalities. First, the standing point of them both is not the states, and both of them adopt compound angles. The former uses angles of both Chinese and members of mankind. It is a Chinese view to see the social process of the world at the height of mankind. The latter uses angles of both Japanese and members of human civilizations. It is a Japanese view to stand on the height of human civilizations to see the process. It seems to be what Professor Onuma means by "hybrid being". ${ }^{13}$ If human beings are understood as people of diverse civilizations, the standing point of the two should be the same. Second, they both emphasize the value of inclusiveness. The key point is whom the inclusiveness should be among. Inclusiveness may be among either different states or different civilizations. From mankind's perspective, inclusiveness should be the latter. In this sense, opening up and inclusiveness as one of the value goals of a community of shared future for mankind, is highly consistent with TCP.

Based on the above considerations, TCP could enlighten Chinese scholars in their theoretical innovation of international law led by the idea of a community of a shared future for mankind.

TCP as a legitimate and feasible approach to international law is a significant contribution by Professor Onuma to the theory of international law. This perspective endows his new book with a unique style and is a crucial complement to general works of international law. The book will also help international lawyers from various civilizations, especially Asian ones, to consider seriously the virtues of their own civilizations and their possibilities for contribution to the development of contemporary international law.

I3. Ibid., at I4. 